\title{
Discovery of endangered annual killifish Austrolebias cheradophilus (Aplocheiloidei: Rivulidae) in Brazil, with comments on habitat, population structure and conservation status
}

\author{
Luis Esteban Krause Lanés ${ }^{1,2}$, Ândrio Cardozo Gonçalves ${ }^{1,3}$ and Matheus Vieira Volcan ${ }^{1,3}$
}

Austrolebias genus comprises about 40 small annual killifishes endemic to South America and their highest diversity occurs in southern Brazil and Uruguay, especially in drainages of Patos-Mirim system. Austrolebias species are severely threatened with extinction because their life cycle and restricted ranges. Low dispersal ability and the extensive loss and fragmentation of freshwater wetlands contribute to this threat. Accurate information on the geographic distribution and ecology of the species, vital to plan conservation and management strategies, are scarce. In order to provide basic knowledge for annual fish conservation this paper reports the presence of Austrolebias cheradophilus and present data about its population structure (CPUA, size, sex ratio, length-weight relationships and condition factor) and conservation status in southern Brazil. The estimated CPUA of populations was $0.86 \mathrm{fish} / \mathrm{m}^{2}$. Standard length (SL) of males ranged between 32.14 and $49.17 \mathrm{~mm}$ and for females between 25.11 and $41.6 \mathrm{~mm}$. There were no differences in SL between the sexes $(t$-test $=-1.678 ; P=0.105)$, and Chi-squared test demonstrated marginal differences in proportions of sexes $(2.25: 1 ; \chi 2=3.846 ; P=0.07)$. Allometric coefficient of the $L W R$ was slightly hyperallometric $(b=3.08)$ and $K$ of the specimens ranged from 1.84 to 2.42 (mean \pm S.E. $=2.12 \pm 0.04$ ). Populations have low density and their biotopes are under critical threat, mainly due to suppression by agriculture, pastures for livestock and increase housing. The species is considered "Critically Endangered" in Brazil, furthermore is strongly recommended its inclusion on lists of endangered fauna and ensures the protection of their remaining habitats.

O gênero Austrolebias compreende cerca de 40 espécies de peixes anuais endêmicos da América do Sul, cuja maior diversidade está concentrada no sul do Brasil e Uruguai, especialmente nas drenagens do sistema hidrográfico Patos-Mirim. A combinação de seu ciclo de vida peculiar com suas restritas distribuições, baixa capacidade de dispersão e ampla fragmentação das áreas úmidas fazem com que suas espécies sejam consideradas ameaçadas de extinção. Entretanto, informações sobre sua distribuição e ecologia são escassas. Visando fornecer informações básicas para a conservação, este estudo registra a presença de Austrolebias cheradophilus no sul do Brasil e apresenta dados sobre sua estrutura populacional (CPUA, tamanho, razão sexual, relação peso-comprimento e fator de condição) e estado de conservação. O CPUA total das populações foi de 0,86 peixe $/ \mathrm{m}^{2}$. Não foram encontradas diferenças no tamanho padrão entre os sexos $(t$-test $=-1,678 ; P=0,105)$ e o teste do Qui-quadrado apresentou um valor marginalmente significativo para a proporção dos sexos $(2,25: 1 ; \chi 2=3.846 ; P=0.07)$. O coeficiente de " $b$ " calculado com base na relação peso-comprimento indica um padrão de crescimento levemente alométrico positivo $(b=3,08)$. O fator de condição dos indivíduos variou entre 1,84 e 2,42 (média \pm S.E. $=2,12 \pm 0,04)$. As populações identificadas têm baixa densidade e estão sob ameaça crítica, principalmente devido à supressão do habitat pela agricultura, pecuária e aumento da urbanização. A espécie foi considerada "Criticamente Ameaçada", portanto recomenda-se sua inclusão em listas de fauna ameaçada e a urgente proteção dos seus habitats.

Key words: Annual fishes, Restricted range, South America, Temporary ponds, Threatened fauna.

\footnotetext{
${ }^{1}$ Instituto Pró-Pampa (IPPampa). Laboratório de Ictiologia. Rua Uruguai, 1242, Centro, 96010-630 Pelotas, Rio Grande do Sul, Brazil. ${ }^{2}$ Universidade do Vale do Rio dos Sinos (UNISINOS). Laboratório de Ecologia e Conservação de Ecossistemas Aquáticos (LECEA), Programa de Pós-Graduação em Biologia - Diversidade e Manejo da Vida Silvestre. Av. Unisinos, 950, Bairro Cristo Rei, $93022-000$ São Leopoldo, Rio Grande do Sul, Brazil. lelanes@gmail.com (LEKL)

${ }^{3}$ Universidade Federal de Santa Maria (UFSM). Programa de Pós-Graduação em Biodiversidade Animal. Av. Roraima 1000, Faixa Camobi, km 09, 97105-900 Santa Maria, Rio Grande do Sul, Brazil.
} 


\section{Introduction}

Austrolebias Costa, a specious genus of the family Rivulidae, comprises about 40 small annual killifishes (Costa, 2008; Ferrer et al., 2008; Loureiro \& García, 2008; Loureiro et al., 2011) endemic to South America and distributed in southern Brazil, southern Bolivia, Paraguay, Uruguay, and north-eastern Argentina (Costa, 2010). The literature indicates that annual fishes, such as Austrolebias species, inhabit temporary wetlands formed during rainy periods and die when the ponds dry out (Costa, 2003, 2006). The embryos survive through resistant diapauses eggs during the dry periods, and hatch after the beginning of the rainy period (Wourms, 1972). When there are regions with no defined rainfall season the presence of water in temporary ponds is mediated by the balance between precipitation, temperature and evaporation (Lanés, 2011).

Morphological (Costa, 2006) and molecular analysis (García, 2006) support the monophyly of the genus and its highest diversity occurs in southern Brazil and Uruguay, especially in drainages of Patos-Mirim hydrographic system (Costa, 2010; Loureiro et al., 2008). The genus was recently phylogenetically redefined, including the species previously referred to Megalebias (Costa, 2006), and divided into sub-genera (Costa, 2008). According to Costa (2006) the Austrolebias elongatus species-group, comprises five valid species [Austrolebias cheradophilus (Vaz-Ferreira, Sierra de Soriano \& Scaglia-de-Paulete), Austrolebias elongatus (Steindachner), Austrolebias monstrosus (Huber), Austrolebias prognathus (Amato) and Austrolebias wolterstorff (Ahl)], reaching a large size (about 70-120 mm SL), which makes some of them the biggest species of the family Rivulidae (Costa, 1998, 2002). After the division of Austrolebias into sub-genera, the $A$. elongatus species-group was allocated in the subgenus Megalebias (Costa, 2008).

These large species are generally top predators of temporary wetland systems, and are rarer than other smaller species of Austrolebias which are often abundant in their habitats (Costa, 2009). This pattern is probably a reflection of increased energy demand, as a function of a larger body size (Laufer et al., 2009; Arim et al., 2010).

The Austrolebias species are severely threatened with extinction because their peculiar life cycle and restricted ranges. Furthermore, their low dispersal ability and the extensive loss and fragmentation of freshwater wetlands and temporary ponds contribute to this threat (Reis et al., 2003; Rosa \& Lima, 2008; Volcan et al., 2009, 2010a; Teixeira de Mello et al., 2011). However for the majority of Austrolebias species (and Rivulidae fishes in general), accurate and timely data on the distribution and ecological information vital to plan conservation and management strategies is absent (Lanés \& Maltchik, 2010; Lanés, 2011). This degree of threat and demand of information about annual fishes resulted in the creation of the "Plano de Ação
Nacional para a Conservação dos Peixes Rivulídeos Ameaçados de Extinção - PAN Rivulídeos" in Brazil (ICMBio, 2013). The main goal of this plan is establish mechanisms for ensure the protection of the species and avoid the loss of their habitats.

Austrolebias cheradophilus occurs in isolated coastal drainages (Costa, 2008) and the Mirim Lagoon basin in Uruguay, where is considered endemic and a priority species for conservation in this country (Teixeira de Mello et al., 2011). Recent studies have reported in southern Brazil the occurrence of species of Austrolebias formerly considered restricted to Uruguay. As an example Austrolebias arachan Loureiro, Azpelicueta \& Garcia (Lanés et al., 2013), Austrolebias melanoorus Amato (Volcan et al., 2011a) and Austrolebias vazferreirai (Berkenkamp, Etzel, Reichert \& Salvia) (Cheffe et al., 2010) were lately recorded in southern Brazil. Besides, several papers report the widening geographical distribution inside Brazil (Lanés \& Maltchik, 2010; Volcan et al., 2010b; Volcan et al., 2010c; Volcan et al., 2011b), showing the incomplete knowledge about the real distribution of these threatened species.

The current paper reports the extension distribution and presence of $A$. cheradophilus in Brazil and provides ecological data about its population structure (results on the sex ratio, length-weight relationships and condition factor), population's threats and environment. Conservation status assessment, based on IUCN criteria is also presented.

\section{Material and Methods}

\section{Study area}

The study area is located in the Coastal Plain of Rio Grande do Sul, the southernmost state of Brazil, and is inserted in the Pampa Biome (IBGE, 2004). Grasslands predominate on flat terrain in this region (IBGE, 2004). The hydrography is represented by the Patos-Mirim Lagoon system, Laguna dos Patos Ecoregion (Abell et al., 2008) which has a drainage area of $13.600 \mathrm{~km}^{2}$, distributed in southern Brazil and eastern Uruguay (Malabarba, 2008). Surveys were directed to the lowlands of Jaguarão River one of the main tributaries of the Mirim Lagoon. The survey area falls within the subtropical climate area, with an average temperature of $13^{\circ} \mathrm{C}$ in the coldest month and above $22^{\circ} \mathrm{C}$ in the warmest month. The hottest months are January and February and the coldest ones are June and July. The average annual rainfall (1200-1500 $\mathrm{mm}$ ) is uniform in all seasons, but varies greatly in different years (Nobre et al., 1986). Although this climate classification indicates a well distributed rainfall throughout the year, there are frequent shortages of soil moisture depending on the drought, coupled with higher evapotranspiration during late spring and summer. During winter and spring, slightly higher precipitations, mainly between June to October, 
result in flooding of lower areas and depressions (Klein, 1997). In the studied region the land is used for agriculture and stockbreeding, mainly temporary crops such as rice and breeding of veal and sheep (IBGE, 2008).

\section{Samplings}

The data for this study were obtained specifically in samplings carried out during September 2009 and July 2011, corresponding to austral winter. During this period, the temporary ponds of the study area generally presents surface water. Although this study may seem casual, other numerous field surveys are being conducted, since 2005 (with exploratory and sporadic visits lasting one to five days), resulting in samples in more than 50 sampling units, distributed in main drainages of Mirim Lagoon, mostly in Jaguarão River basin, and resulting in the discovery of several other annual fish species and populations (Lanés et $a l$. ., pers. obs.). Even these surveys resulted in the discovery of Austrolebias univentripinnis Costa \& Cheffe and provided important material for describing Austrolebias juanlangi Costa, Cheffe, Salvia \& Litz and Austrolebias nachtigalli Costa \& Cheffe. For more details see Costa (2006).

At the sampling sites, the co-ordinates, area $\left(\mathrm{m}^{2}\right)$ and elevation (meters above sea level) were estimated using GPS, and the physical and chemical parameters of water $(\mathrm{pH}$, dissolved oxygen $\left(\mathrm{mg} \mathrm{L}^{-1}\right)$, conductivity $\left(\mu \mathrm{S} \mathrm{cm}^{-1}\right)$ and temperature $\left({ }^{\circ} \mathrm{C}\right)$ ) were assessed with portable devices (Hanna HI 9828).

Fish samples were taken with a dip-net (D-shaped hand net, $60 \mathrm{~cm} \times 30 \mathrm{~cm}, 2 \mathrm{~mm}$ mesh size), and then were euthanized with a lethal dose of clove oil, fixed in situ with $10 \%$ formalin, and later transferred into $70 \%$ ethanol. Sampling was performed by sweeping the net parallel to the pond bottom, exploring a variety of habitats of the wetlands. Fifty sweeps (corresponding each to approx. $0.6 \mathrm{~m}^{2}$ of sampled area) were carried out per sampling site. The chosen sampler mesh-size was fine enough to capture all sizes of Austrolebias fishes present at a sampling site. Specimens were identified and sexed based on Costa (2006). The material was collected under IBAMA/ICMBio authorization (process number 18334-1 and 18334-2) and vouched in ichthyologic collection of Universidade Federal do Rio de Janeiro (UFRJ 6748 - nine specimens preserved in alcohol; UFRJ 6749 - five specimens cleared and counterstained).

\section{Data analysis}

Abundance was assessed by the total number of captured fishes and expressed as catch per unit area (CPUA: number of individuals $/ \mathrm{m}^{2}$ ). A Student's $t$-test was performed to explore differences between the mean standard body length (SL) of males and females. The possible bias of the sex ratio of the studied population from the expected 1:1 rate were determined by Chi-square test (with at $95 \%$ significance level) with randomization by Monte Carlo method.

The specimens were measured in standard length (SL) to the nearest $0.1 \mathrm{~mm}$ and weighed (body weight including the gonads) to the nearest $0.001 \mathrm{~g}$ to assess the length-weight relationship ( $L W R$ ). The $L W R, W=a \mathrm{~L}^{\mathrm{b}}$, was transformed into its logarithmic expression: $\log W=\log (a)+b^{*} \log$ (SL), where $a$, is the intercept and $b$ is the slope. The relationships between standard length and weight were determined by least square regression. The $95 \%$ confidence limits for $b\left(\mathrm{CL}_{95 \%}\right)$ were calculated to determine if the hypothetical isometry value $(b=3)$ fell between these limits (Froese, 2006). Condition factor $(K)$ coefficients of $A$. cheradophilus were calculated as the ratio between body weight and standard length, through the following equation: $K=\left(W / \mathrm{SL}^{b}\right)^{*} 100$, where the $(b)$ represents the slope of the length-weight relationship.

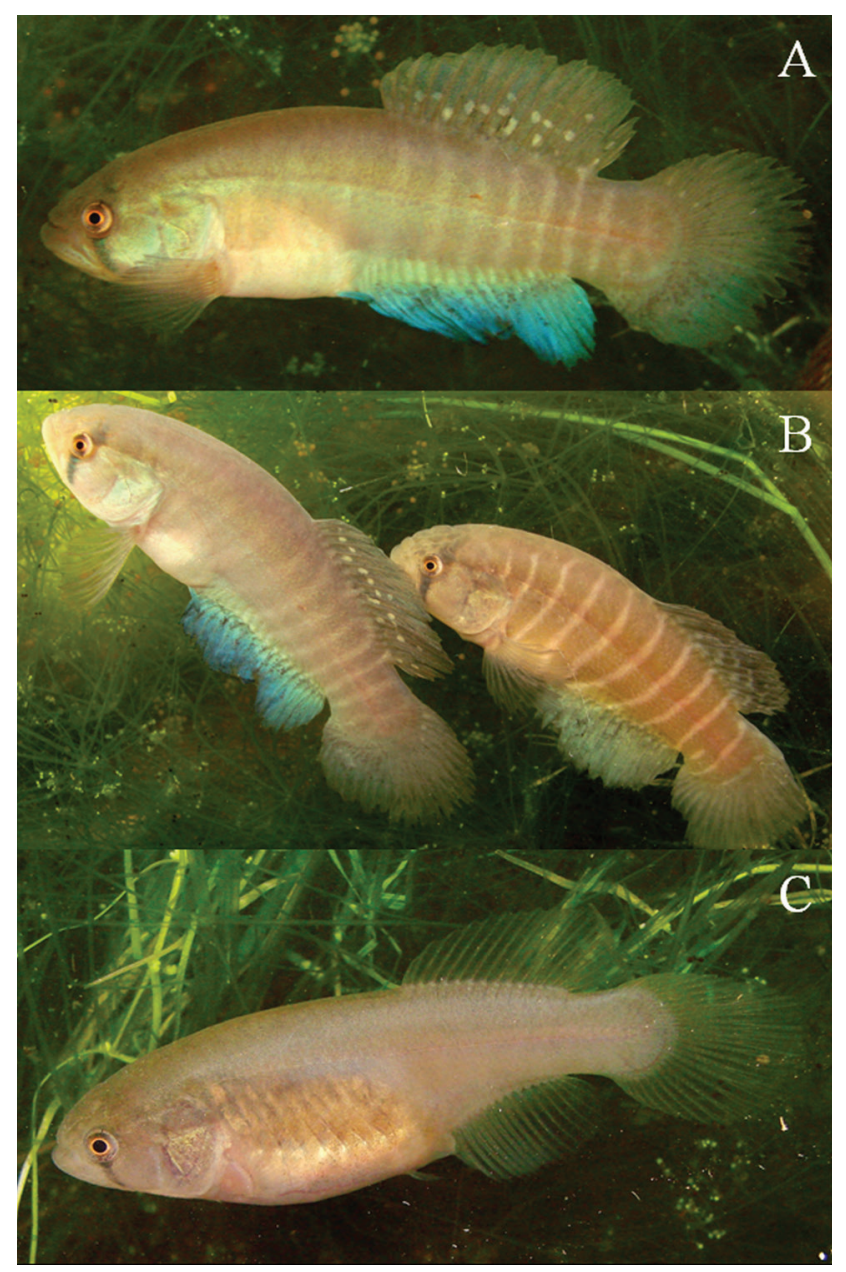

Fig. 1. Austrolebias cheradophilus sampled in Jaguarão River, Patos-Mirim Lagoon system, southern Brazil: (A) Male, $49.2 \mathrm{~mm} \mathrm{SL}$, (B) variation in color pattern of males (41.3 $\mathrm{mm}$ and $49.2 \mathrm{~mm} \mathrm{SL}$ ) and (C) female, $41.2 \mathrm{~mm} \mathrm{SL}$. Photos by Matheus Volcan. 

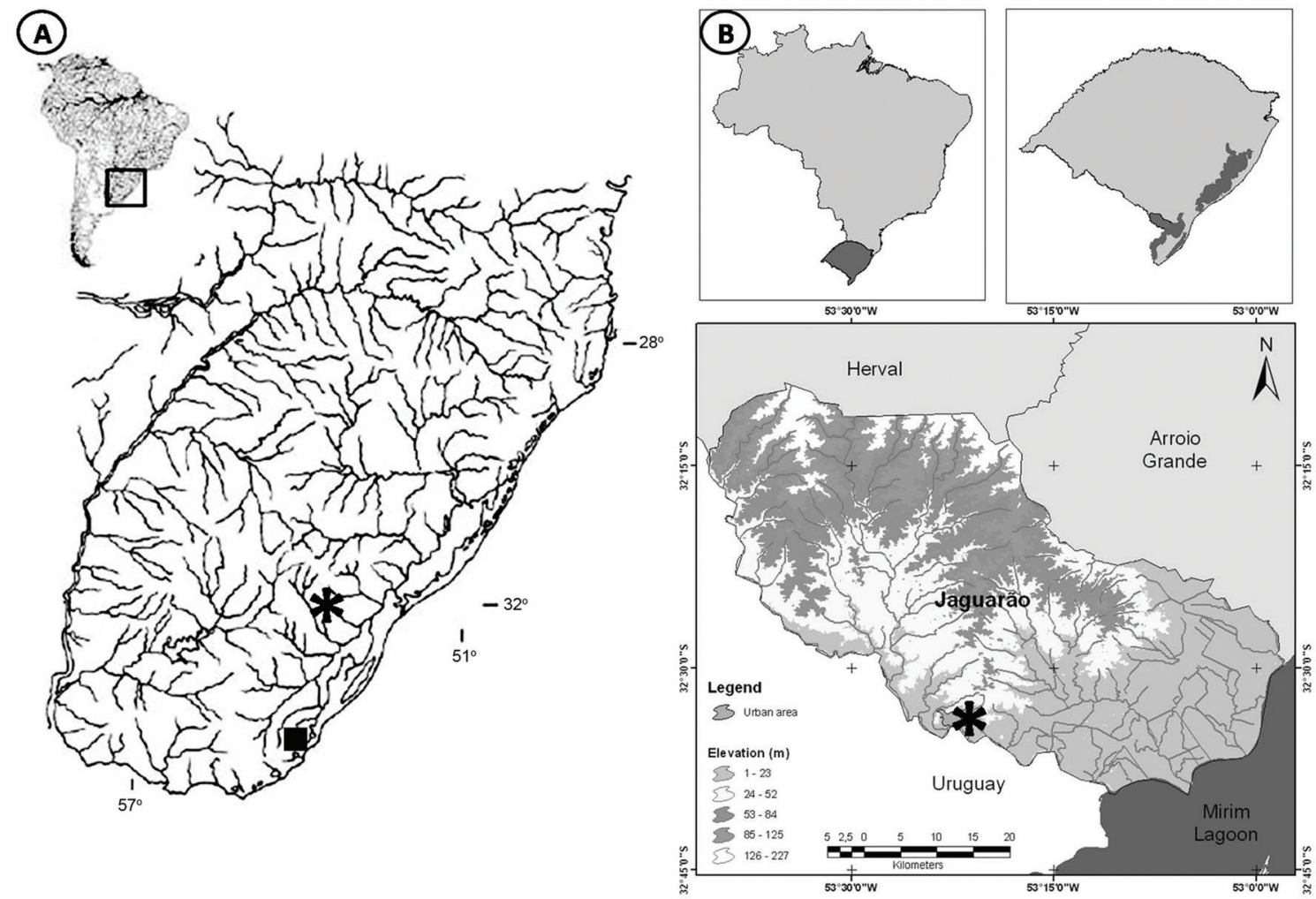

Fig. 2. (A) Occurrence of Austrolebias cheradophilus in Jaguarão River basin, Patos-Mirim Lagoon system, southern Brazil (asterisc), and previous record of the species closest to Brazil (Black square). (B) Map detailing the occurrence of the species in lower Jaguarão River, Patos-Mirim Lagoon system, southern Brazil.

\section{Conservation assessment}

Conservation status assessment was based on field surveys. To establish the vulnerability category the IUCN criteria were applied (IUCN, 2011), using criterion B2 (Geographic range in the form of either B2 - area of occupancy). Currently this approach is applied in the revaluation of the red lists of threatened fauna of Rio Grande do Sul State (Fontana et al., 2003), Brazil (Rosa \& Lima, 2008), and "Plano de Ação Nacional para a Conservação dos Rivulídeos - PAN Rivulideos" (ICMBio, 2013). Areas of occupancy (AOO) and distances were calculated using satellite images available in Google Earth (earth.google. com). Wetland boundaries were determined based on (1) visual observations of the watermarks and (2) vegetation indicators (e.g., plants with morphological, physiological or reproductive adaptations to prolonged saturation/inundation and the proportion between aquatic and terrestrial species in the plant community).

\section{Results}

Two populations of A. cheradophilus (Fig. 1) were discovered in southern Brazil, Jaguarão town, associated with a small tributary stream located in lowlands of Jaguarão River drainage,
Patos-Mirim Lagoon hydrographic system (Fig. 2). This study provides the first record of the species in Brazil, extending its distribution $150 \mathrm{~km}$ northwards (Fig. 2) and constitutes the first citation of Megalebias subgenus in Jaguarão River basin.

Both populations (Site 1 and Site 2) were found in similar environments, represented by small $\left(<1 \mathrm{~km}^{2}\right)$ and shallow $(<30 \mathrm{~cm})$ temporary palustrine ponds (represented by small ground depressions) located in grassland areas of private farms surrounding Jaguarão town (Fig. 3). The two newly-discovered localities inhabited by A. cheradophilus are hydrologically isolated and separated by $c a .750$ meters. Soil preparation activities for exotic pasture culture were observed on the surrounding areas after the species discovery. There are a local road, small groves of eucalyptus, houses and pastures for cows and horses between the two identified locations. The sites are not covered by protected areas. Wetland vegetation was dense and abundant, composed mostly of emergent macrophytes; mainly Eryngium sp. and floating rooted (Echinodorus spp., Leersia hexandra, Luziola peruviana, Ludwigia peploides, L. grandflora, Marsilea spp., Myriophyllum aquaticum, Nymphoides indica, Regnellidium diphyllum, Polygonum hydropiperoides) and submerged plants (Scirpus submersus, Urtricularia gibb), forming 
multispecific stands. The only other fish species found in co-occurrence with A. cheradophilus were the non-annual fishes Cheirodon interruptus (Jenyns), Callichthys callichthys (Linnaeus) and Phalloceros caudimaculatus (Hensel). Details of environmental and water characterization of each sampling site are shown in Table 1.

A total of 26 specimens of A. cheradophilus (8 males and 18 females) were sampled throughout the study. The specimens were found only in shallow areas (mean \pm S.E. $=$ $10 \pm 1.30 \mathrm{~cm}$ ) of the ponds. The total CPUA of populations was $0.86 \mathrm{fish} / \mathrm{m}^{2}$. There was a variation of CPUA values among sampling sites, being higher in the site 1 (1.2 vs. 0.6 fish $/ \mathrm{m}^{2}$ in site 2) (Table 2). The SL of males ranged between 32.14 and $49.17 \mathrm{~mm}$ (mean \pm S.E. $=39.27 \pm 2.41 \mathrm{~mm}$ ) and of females between 25.11 and $41.6 \mathrm{~mm}$ (mean \pm S.E. $=$ $35.06 \pm 1.29 \mathrm{~mm}$ ). Even though the larger caught fish were males, there were no significant differences in SL between the sexes $(t$-test $=-1.678 ; P=0.105)$. The Chi-squared test demonstrated marginal significant differences in proportions of sexes $(2.25: 1 ; \chi 2=3.846 ; P=0.07)$. Information about variations in the number of sampled specimens, CPUA, and SL range, in each sampling site for each sex are given in Table 2.

Length-weight relationship of $A$. cheradophilus $\left(r^{2}=\right.$ $0.961 ; P=0.0001)$ in the form of a regression equation was estimated as $\log W=-2.596+3.083 \log \mathrm{SL}$ and the allometric coefficient " $b$ " of the LWR was slightly hyperallometric $\left(b=3.08 ; \mathrm{CI}_{95 \%}=2.348\right.$ to 3.519$)$. The condition factor of the specimens ranged from 1.84 to 2.42 (mean \pm S.E. $=2.12 \pm 0.04$ ).

In accordance with application of IUCN criteria, Austrolebias cheradophilus was considered as "Critically Endangered" species in Brazil, being included in the criteria CR B2ab (ii, iii). The species presents reduced area of occupancy (AOO less than $10 \mathrm{~km}^{2}$ ), populations severely fragmented (a) and continued decline (b) in area of occupancy (ii) and quality of habitat (iii).

Table 1. Environmental and water characterization of sampling sites of Austrolebias cheradophilus populations found in Jaguarão River basin, Patos-Mirim Lagoon system, southern Brazil.

\begin{tabular}{lcc}
\hline \multicolumn{1}{c}{ Variables } & Site 1 & Site 2 \\
\hline Geographic coordinates & $32^{\circ} 33^{\prime} \mathrm{S} 53^{\circ} 21^{\prime} \mathrm{W}$ & $32^{\circ} 33^{\prime} \mathrm{S} 53^{\circ} 20^{\prime} \mathrm{W}$ \\
Elevation $(\mathrm{m})$ & 25 & 23 \\
Estimated area $\left(\mathrm{m}^{2}\right)$ & 3776 & 7500 \\
Depth $(\mathrm{cm})$ & 25 & 19 \\
Dissolved oxygen $(\mathrm{mg} / \mathrm{L})$ & 4.28 & 4.63 \\
$\mathrm{pH}$ & 6.85 & 8.23 \\
Conductivity $(\mathrm{mS} / \mathrm{cm})$ & 0.026 & 0.019 \\
Temperature $\left({ }^{\circ} \mathrm{C}\right)$ & 10.87 & 12.13 \\
\hline
\end{tabular}

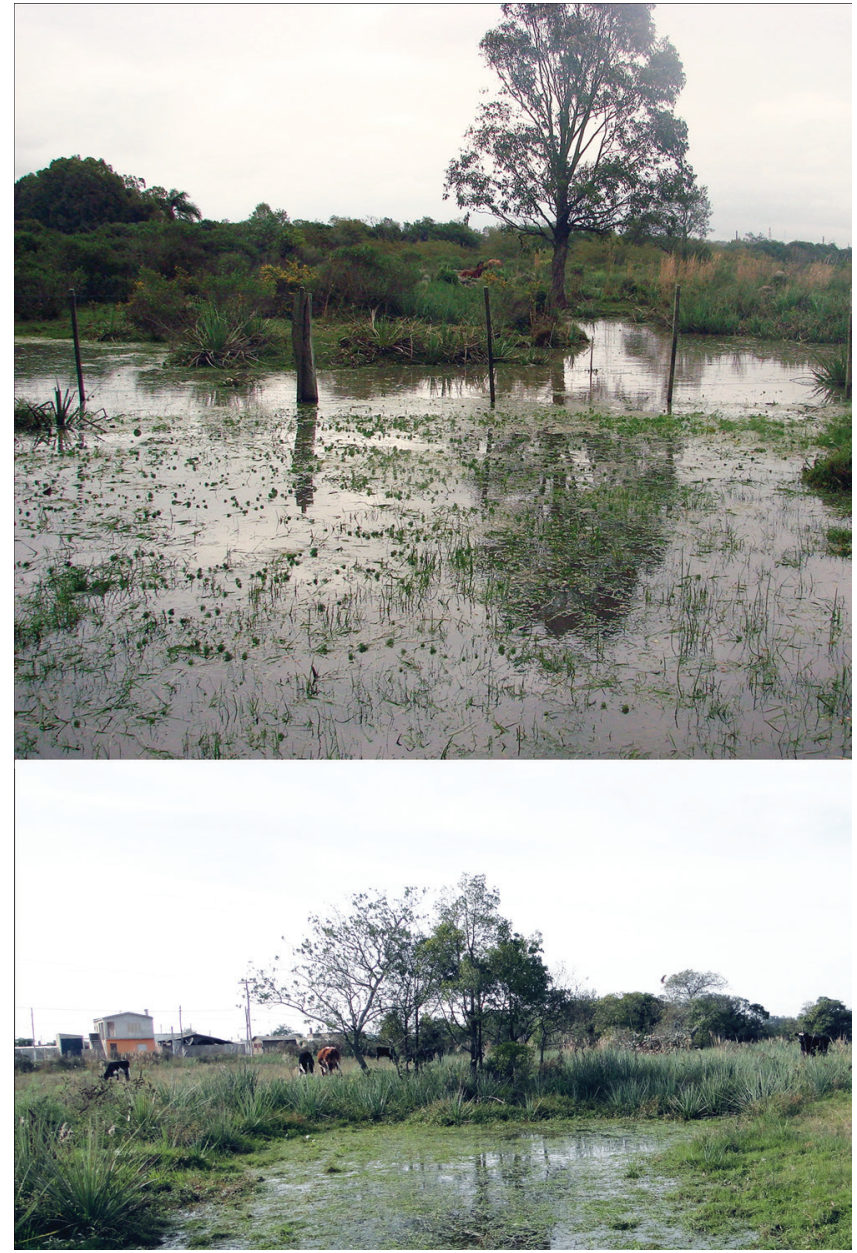

Fig. 3. Temporary ponds (Site 1 above and Site 2 below) inhabited by Austrolebias cheradophilus in lowlands of Jaguarão River basin, southern Brazil.

\section{Discussion}

This paper reports a significant range extension in the known distribution of $A$. cheradophilus, especially considering the low vagility of the Austrolebias species (Loureiro et al., 2011; Garcia et al., 2012). Until recently A. cheradophilus was considered exclusive of isolated coastal drainages (Costa, 2003, 2006, 2008), despite the existence of an unpublished record in the Cebollati Stream, Mirim Lagoon basin, in Uruguay (Muséum national d'histoire naturelle, MNHN 1997-411) (Froese \& Pauly, 2011), $150 \mathrm{~km}$ far from this record. Recently Teixeira de Mello et al. (2011) formalized the occurrence of the species in Lagoa Mirim basin. The present-day distribution of $A$. elongatus species-group was hypothesized as a result of dispersal event from Patos (ancestor) to the Paraguay hydrographic system through La Plata area (Costa, 2010), and the occurrence of species in the Patos-Mirim system is probably related to ancient connections between this system and coastal drainages of Uruguay. 
Table 2. Sex ratio, number of sampled specimens $(n)$, CPUA (fishes $\left./ \mathrm{m}^{2}\right)$, and standard length (SL in mm; minimum - maximum) of $A$. cheradophilus between sampling sites in southern Brazil.

\begin{tabular}{lccccccc}
\hline & Male & Female & $\boldsymbol{n}$ & CPUA & SL Male & SL Female & SL M+F \\
\hline Site 1 & 6 & 11 & 17 & 1.2 & 32.14 to 49.17 & 25.11 to 41.24 & 25.11 to 49.17 \\
Site 2 & 2 & 7 & 9 & 0.6 & 33.1 to 44.9 & 31.7 to 41.6 & 31.7 to 44.9 \\
Total & 8 & 18 & 26 & 0.86 & 32.14 to 49.17 & 25.11 to 41.6 & 25.11 to 49.17 \\
\hline
\end{tabular}

Considering also the present study there are 22 species of the genus Austrolebias in Rio Grande do Sul State (Lanés, 2011; Lanés et al., 2013), which represent more than half of all diversity of the genus (Costa, 2006, 2008; Loureiro et al., 2011). It shows that this territory is an important center of endemism and diversity of this group. Six of them $(A$. arachan, A. cheradophilus, A. juanlangi, A. melanoorus, $A$. nachtigalli, and $A$. univentripinnis) has records in Brazilian drainages of Jaguarão River basin (Costa, 2006; Volcan et al., 2011a; Lanés et al., 2013). Moreover, the recent descriptions of Austrolebias reicherti Loureiro \& García and of Austrolebias quirogai Loureiro, Duarte \& Zarucki in Jaguarão River basin in Uruguay, indicate that probably they also occur in Brazil. Unfortunately, despite the large representation of species with conservation importance, there is no protected area in Jaguarão River drainages (Lanés et al., 2013).

The CPUA values obtained suggest that the species occur in low densities in the investigated localities. Other studies found 2.2 individuals per sampled area of $1 \mathrm{~m}^{2}$ for a population of $A$. arachan (Lanés et al., 2013), and 1.97 for Atlantirivulus riograndensis (Costa \& Lanés) (Lanés et al., 2012). Larger species of rivulids (such as Megalebias subgenus) are generally rarer than small species. Species of Megalebias subgenus were found at relatively low densities in areas where distinct rivulid species co-occurs (Laufer et al., 2009; Arim et al., 2010; Volcan et al., 2013).

Although males of $A$. cheradophilus were less abundant and larger than the females, there were no significant differences in the proportion of individuals and standard size between the sexes. This result may be assigned to the natural rarity of the species and to the small size of our samples, since the males of Austrolebias usually are larger and less abundant than females (Costa, 2003; Lanés et al., 2013). Laufer et al. (2009) found differences in these aspects in other species of Austrolebias with abundant population, but as in this study, also hasn't found difference in $A$. cheradophilus, attributing this result to its small sample size. The $P$-values of 0.10 for size differences and of 0.07 for sex ratio can therefore be considered as marginally significant and they suggest a trend of difference in these parameters between the sexes.

Allometric coefficients $(b)$ of $L W R$ estimated for the species fell within the expected range of 2.5-3.5 (Froese, 2006). The slightly hyperallometric growth found in this study suggests that analyzed specimens increases minimally more in weight $(\mathrm{W})$ than predicted by the increase in length (SL). No previous references for $L W R$ of $A$. cheradophilus were available making difficult the comparisons with other previous studies. Austrolebias wolterstorffi, other member of Megalebias subgenus showed positive allometric growth $(b=3.04)$ when kept under laboratory conditions (Fonseca et al., 2013), with values very similar to those found in this study and Volcan et al. (2013) found highly positive allometric growth for wild populations of $A$. wolterstorffi $(b=3.26)$. The same growth pattern found in this study was observed for other Austrolebias species, such as Austrolebias viarius (Vaz-Ferreira, Sierra-de-Soriano \& Scaglia-de-Paulete) (Errea \& Danulat, 2001), Austrolebias nigrofasciatus (Costa \& Cheffe) (Volcan et al., 2013) and A. arachan (Lanés et al., 2013).

Austrolebias cheradophilus is considered "Priority Species for the Conservation in Uruguay" (Teixeira de Mello et al., 2011), because it's restricted distribution, low representation in fish collections and economic value (for aquarium). Although these new populations' records and the distribution expansion of the species to Brazil are important, is not sufficient to ensure its conservation. In accordance with application of IUCN criteria, the species is considered "Critically Endangerd" in Rio Grande do Sul State and Brazil. The Red List Criteria represents a first step in setting priorities for conservation action (IUCN, 2011).

Therefore, the inclusion of $A$. cheradophilus in future listings of threatened fauna is strongly recommended. However the most important and effective action for conservation species in Brazil is the protection of their remaining habitats, since the populations are highly restricted, have low density and their biotopes are under critical threat, mainly due to suppression by the land use for agriculture, livestock (replacement of natural grassland areas by pastures for grazing) and increase urbanization. The conservation of small and seasonal ponds is essential for the maintenance of annual fish species. Knowing the geographic distribution and environment of endangered species is critical as baseline for future studies, conservation strategies and environmental licensing. In this sense, our study provides a first insight about population parameters and habitat features related to the occurrence of Austrolebias cheradophilus in Brazil. 


\section{Acknowledgments}

This study was partially funded by project "Peixes Anuais do Pampa" of the "Fundação Grupo Boticário de Proteção à Natureza". We are grateful to Dr. Wilson Costa by examining the material, confirming the identification and providing voucher numbers of the species record. This paper was improved by the comments of two anonymous reviewers.

\section{Literature Cited}

Abell, R., M.L. Thieme, C. Revenga, M. Bryer, M. Kottelat, N. Bogutskaya, B. Coad, N. Mandrak, S. C. Balderas, W. Bussing, M. L. J. Stiassny, P. Skelton, G. R. Allen, P. Unmack, A. Naseka, R. Ng, N. Sindorf, J. Robertson, E. Armijo, J. V. Higgins, T. J. Heibel, E. Wikramanayake, D. Olson, H. L. López, R. E. Reis, J. G. Lundberg, M. H. S. Pérez \& P. Petry. 2008. Freshwater Ecoregions of the World: A New Map of Biogeographic Units for Freshwater Biodiversity Conservation. Bio Science, 58: 403-414.

Arim, M., S. B. Abades, G. Laufer, M. Loureiro \& P. Marquet. 2010. Food web structure and body size trophic position and resource acquisition. Oykos, 119: 147-153.

Cheffe, M. M., M. V. Volcan \& L. E. K. Lanés. 2010. Pisces, Cyprinodontiformes, Rivulidae, Austrolebias vazferreirai (Berkenkamp, Etzel, Reichert and Salvia, 1994): new species record from Brazil. Check List, 6: 592-593.

Costa, W. J. E. M. 1998. Phylogeny and classification of Rivulidae revisited: evolution of annualism and miniaturization in rivulid fishes (Cyprinodontiformes: Aplocheiloidei). Journal of Comparative Biology, 3: 33-92.

Costa, W. J. E. M. 2002. Monophyly and phylogenetic relationships of the neotropical annual fish genera Austrolebias and Megalebias (Cyprinodontiformes: Rivulidae). Copeia, 2002: 916-927.

Costa, W. J. E. M. 2003. Family Rivulidae (South American annual fishes). Pp. 526-548. In: Reis, R. E., S. O. Kullander \& C. J. Ferraris Jr. (Orgs.). Check List of the Freshwater Fishes of the South and Central America. Porto Alegre, Edipucrs.

Costa, W. J. E. M. 2006. The South American annual killifish genus Austrolebias (Teleostei: Cyprinodontiformes: Rivulidae): phylogenetic relationships, descriptive morphology and taxonomic revision. Zootaxa, 1213: 1-162.

Costa, W. J. E. M. 2008. Catalog of aplocheiloid killifishes of the word. Rio de Janeiro, Reproarte.

Costa, W. J. E. M. 2009. Trophic radiation in the South American annual killifish genus Austrolebias (Cyprinodontiformes: Rivulidae). Ichthyological Explorations Freshwaters, 20: 179-191.

Costa, W. J. E. M. 2010. Historical biogeography of Cynolebiasine annual killifishes inferred from dispersal-vicariance analisys. Journal of Biogeography, 37: 1995-2004.

Errea, A. \& E. Danulat. 2001. Growth of the annual fish, Cynolebias viarius (Cyprinodontiformes), in the natural habitat compared to laboratory conditions. Environmental Biology of Fishes, 61: 261-268.

Ferrer, J., L. R. Malabarba \& W. J. E. M. Costa. 2008. Austrolebias paucisquama (Cyprinodontiformes: Rivulidae), a new species of annual killifish from southern Brazil. Neotropical Ichthyology, 6: 175-208.

Fonseca, A. P., M. V. Volcan, L. A. Sampaio, L. A. Romano \& R. B. Robaldo. 2013. Growth of Critically Endangered annual fish Austrolebias wolterstorffi (Cyprinidontiformes: Rivulidae) at different temperatures. Neotropical Ichthyology, 11(4): 837-844
Froese, R. \& D. Pauly (Eds.). 2011. FishBase. World Wide Web electronic publication. Available from: http:/www.fishbase.org, version (01/2011) (10 November 2011).

García, G. 2006. Multiple simultaneous speciation in killifishes of the Cynolebias adloffi species complex (Cyprinodontiformes, Rivulidae) from phylogeography and chromosome data. Journal of Zoological Systematics and Evolutionary Research, 44: 75-87.

IBGE (Instituto Brasileiro de Geografia e Estatística). 2004. Mapa da Vegetação e dos Biomas do Brasil. Available from: www.ibge. gov.br (22 May 2011).

IBGE (Instituto Brasileiro de Geografia e Estatística). 2008. Produção Agrícola Municipal 2007. Available from: www.ibge.gov.br (10 April 2011).

ICMBio (Instituto Chico Mendes de Conservação da Biodiversidade). 2013. Sumário Executivo do Plano de Ação Nacional para a Conservação dos Peixes Rivulídeos Ameaçados de Extinção. Brasília. Available from: http://www.icmbio.gov.br/portal/ images/stories/docs-plano-de-acao/pan-rivulideos/sumarioexecutivo-rivulideos.pdf (14 April 2013).

IUCN Standards and Petitions Subcommittee. 2011. Guidelines for Using the IUCN Red List Categories and Criteria, Version 9.0, Standards and Petitions Subcommittee, 87p. Available from: http:/www.iucnredlist.org/documents/RedListGuidelines.pdf (16 March 2013).

Klein, A. H. F. 1998. Clima regional. Pp. 5-7. In: Seeliger, U., C. Odebrecht \& J. P. Castello (Eds.). Os ecossistemas costeiro e marinho do extremo sul do Brasil. Ecoscentia, Rio Grande, Brazil.

Lanés, L.E.K. 2011. Dinâmica e conservação de peixes anuais (Cyprinodontiformes: Rivulidae) no Parque Nacional da Lagoa do Peixe. Unpublished M.Sc. Dissertation, Universidade do Vale do Rio dos Sinos (UNISINOS), São Leopoldo, Rio Grande do Sul, Brazil. 69p.

Lanés, L. E. K. \& L. Maltchik. 2010. Discovery of the annual killifish Critically Endangered, Austrolebias wolterstorffi (Ahl, 1924) (Rivulidae: Cyprinodontiformes) in Lagoa do Peixe National Park, Rio Grande do Sul, southern Brazil. Journal of Threatened Taxa, 2: 1282-1285.

Lanés, L. E. K., Â. C. Gonçalves \& M. V. Volcan. 2013. Austrolebias arachan Loureiro, Azpelicueta \& García 2004 (Cyprinodonfiformes: Rivulidae) in Rio Grande do Sul, Brazil: occurrence, length-weight relationships and condition factor. Journal of Applied Ichthyology, 29: 252-256.

Laufer, G., M. Arim, M. Loureiro, J. M. Piñero-Guerra, S. ClavijoBaque \& C. Fagúndez. 2009. Diet of four annual killifishes: an intra and interspecific comparision. Neotropical Ichthyology, 7: 77-86.

Loureiro, M. \& G. García. 2008. Austrolebias reicherti Loureiro \& García, a valid species of annual fish (Cyprinodontiformes: Rivulidae) from Uruguay. Zootaxa, 1940: 1-15.

Loureiro, M., A. Duarte \& M. Zarucki. 2011. A new species of Austrolebias Costa (Cyprinodontiformes: Rivulidae) from northeastern Uruguay, with comments on distribution patterns. Neotropical Ichthyology, 9: 335-342.

Malabarba, L. R. 2008. Catálogo dos peixes de água doce do Sistema da Laguna dos Patos. Available from: http://www.ufrgs.br/ictio/ lagunapatos/ (12 March 2012).

Maltchik, L., L. E. K. Lanés, C. Stenert \& E. S. F. Medeiros. 2010. Species-area relationship and environmental predictors of fish communities in coastal freshwater wetlands of southern Brazil. Environmental Biology of Fishes, 88: 25-35.

Nobre, C.A., I. F. de A. Cavalcanti, M. A. Gan, P. Nobre, M. T. Kayano, B. R. Vadlamudi, J. P. Bonatti, P. Satyamurty, C. B. Uvo, J. C. 
Cohen, J. de F. da Silva, C. Marschal, A. D. Moura. 1986. Aspects of dynamic climatology of Brazil. Clima análise Special Issue.

Reis, R. E., Z. M. S. Lucena, C. A. S. Lucena \& L. R. Malabarba. 2003. Peixes. Pp. 117-145. In: Fontana, C. S., G. A. Bencke \& R. E. Reis (Eds.). Livro Vermelho da Fauna Ameaçada de Extinção no Rio Grande do Sul. Porto Alegre, Edipucrs.

Rosa, R. S. \& F. C. T. Lima. 2008. Peixes. Pp. 09-285. In: Machado, A. B. M., G. M. Drummond \& A. P. Paglia (Eds.). Livro vermelho da fauna brasileira ameaçada de extinção. Brasília, Ministério do Meio Ambiente.

Teixeira de Mello, F., González-Bergonzoni, I. \& Loureiro, M. 2011. Freshwater Fishes of Uruguay. PPR-MGAP.

Volcan, M. V., L. E. K. Lanés \& Â. C. Gonçalves. 2009. Threatened fishes of the world: Austrolebias nigrofasciatus Costa and Cheffe 2001 (Cyprinodontiformes: Rivulidae). Environmental Biology of Fishes, 86: 319-320.

Volcan, M. V., L. E. K. Lanés \& Â. C. Gonçalves. 2010a. Threatened fishes of the world: Austrolebias univentripinnis Costa \& Cheffe 2005 (Cyprinodontiformes: Rivulidae). Environmental Biology of Fishes, 87: 443-444.

Volcan, M. V., L. E. K. Lanés \& Â. C. Gonçalves. 2010b. Pisces, Cyprinodontiformes, Rivulidae, Austrolebias periodicus (Costa, 1999): Distribution extension in State of Rio Grande do Sul, southern Brazil. Check List, 6: 234-236.

Volcan, M. V., L. E. K. Lanés \& M. M. Cheffe. 2010c. Distribuição e Conservação de Peixes Anuais (Cyprinodontiformes, Rivulidae) no município do Chuí, Brasil. Biotemas, 23: 51-58.
Volcan, M. V., L. E. K. Lanés, Â. C. Gonçalves \& M. M. Cheffe. 2011a. First record of annual killifish Austrolebias melanoorus (Amato, 1986) (Cyprinodontiformes: Rivulidae) from Brazil, with data on habitat and conservation. Journal of Applied Ichthyology, 27: 1120-1122.

Volcan, M. V., Â. C. Gonçalves \& L. E. K. Lanés. 2011b. Distribution, habitat and conservation status of two threatened annual fishes (Rivulidae) from southern Brazil. Endangered Species Research, 13: $79-85$

Volcan, M. V., Â. C. Gonçalves \& D. L. Guadagnin. 2013. Lengthweight relationship of three annual fishes (Rivulidae) from temporary freshwater wetlands of southern Brazil. Journal of Applied Ichthyology. doi:10.1111/jai.12214

Wourms J. P. 1972. The developmental biology of annual fishes. III. Pre embryonic and embryonic diapause of variable duration in the eggs of annual fishes. Journal of Experimental Zoology, 182: 389-414. 